\title{
Wat het Athene met Jerusalem te doen? Enkele histo- ries-sistematiese gesigspunte in verband met die vraag of die teologie aan die universiteit tuishoort
}

C J Wethmar

\section{ABSTRACT}

Jerusalem and Athens: A few historical and systematic considerations regarding the position of theology at state universities

This article investigates the question whether theology as an academic discipline should be accommodated at state universities. This question proves to be determined by a complex constellation of historical, philosophical, theological and political issues. In an attempt to give a systematic analysis and evaluation of these issues a brief historical description of the relationship between theology and university is given and the basic characteristics of a university and theology identified. Such an approach seems to provide adequate considerations for motivating an affirmative answer to the question at stake.

\section{INLEIDING}

Sedert die Nederduitse Gereformeerde Kerk met die opleiding van sy predikante aan die Universiteite van Stellenbosch en Pretoria begin het, is sowel die morele as wetenskapsteoretiese reg daarvan as vanselfsprekend aanvaar ${ }^{1}$. Die stigting van die teologiese fakulteit aan die Universiteit van die Oranje Vrystaat staan ook nog in die teken hiervan, alhoewel daar op daardie stadium reeds kritiese vrae oor die regmatige bestaan van kerklike teologiese fakulteite aan staatsondersteunde universiteite na vore begin kom het $^{2}$. Dit is vanselfsprekend dat die politieke transformasieproses wat tans in Suid-Afrika aan die gang is hierdie vrae sterk sal radikaliseer ${ }^{3}$. Namate 'n staatsbestel ontwikkel wat amptelik nie meer eksklusief aan die Christendom georiënteer is nie, maar wat ten opsigte van godsdienstige aangeleenthede 'n neutrale houding aanneem, is dit vanselfsprekend dat die Christelike teologie nie meer om piëteitsredes aan staatsondersteunde onderwysinstellings welkom sal wees soos lank die geval was nie. Die teologie sal moet kan aantoon dat sy voortgesette teenwoordigheid aan dergelike instansies op geldige wetenskaplike en morele gronde berus. Daarby is eweneens te verwag dat ' $n$ snel toenemende proses van sekulari- 
sasie sal bydra tot 'n algemene lewens- en wêreldbeskouing waarbinne die Christelike geloof 'n steeds kleiner wordende rol sal speel.

Wat wel belangrik is om in te sien, is dat alhoewel die verskynsels van religieuse neutraliteit enersyds en sekularisasie andersyds juis in die huidige tyd na vore tree as begeleidingsverskynsels van die politieke transformasieproses in Suid-Afrika, hulle nie uitsluitlik daardeur veroorsaak word nie. Dit gaan hier om prosesse wat in die breër internasionale wêreld aan die ontwikkel is en wat in elk geval ook in SuidAfrika aan die kom was. En die probleme wat hierdie prosesse meebring vir die teologie-beoefening in die algemeen en ten opsigte van die plek van teologiese fakulteite aan staatsondersteunde universiteite in die besonder, is wel binne die konteks van die Afrikaanstalige kerke van betreklik resente datum maar vanuit 'n historiese en internasionale perspektief beskou, is dit 'n ontwikkeling wat te voorsien was. Dit gaan hier immers om 'n verskynsel wat al sowat twee eeue die gemoedere van belanghebbendes in beweging het. Met 'n opvallende reëlmaat is die vraag of die teologie aan die universiteit tuishoort steeds weer in alle lande wat daarvoor in aanmerking kom, aan die orde gestel.

Alhoewel die indruk soms bestaan dat die problematisering van die verhouding tussen teologie en universiteit slegs aan die teologie toegeskryf moet word, dui resente ondersoek daarop dat die probleme met albei vennote in hierdie verhouding verbandhou ${ }^{4}$. Trouens, dit het algaande duideliker geword dat die vraagstukke waarvan hier sprake is nie behoorlik gepeil kan word as nie ook rekening gehou word met die totaliteit van die konteks waarin die universiteit en die teologie met mekaar in verhouding staan nie. Dit beteken dat gevra moet word hoe die teologie verbandhou met die Christelike geloof en die kerk waarin dit bely word. Maar ook moet daar gekyk word na die invloed van die teologie op en die beïnvloeding daarvan deur die maatskaplike en politieke omstandighede waarin dit 'n rol speel.

Die Amerikaanse teoloog David Tracy het die kwessies wat hier aan die orde kom goed gesistematiseer deur te beklemtoon dat die teologie voor drie gehore ("publics") optree, tewete die samelewing, die akademie en die kerk $^{5}$. Wie die verhouding tussen teologie en universiteit wil peil, sal rekening moet hou met die komplekse en spanningsvolle konstellasie wat gevorm word deur die inwerking op mekaar van die vermelde drie gehore waarin die teologie steeds funksioneer6.

Maar nog afgesien van die ingewikkelde konteks waarin die verhouding tussen teologie en universiteit verduidelik moet word, blyk dat die begrippe teologie en universiteit in die huidige tyd nie sonder meer 
duidelik is nie ${ }^{7}$. Die betreklik eenvormige wêreld waarin die universiteitswese aanvanklik met die oorgang van die twaalfde na die dertiende eeu tot stand gekom het, het met die aanbreek van die moderne en postmoderne tyd in 'n pluralisme van lewens- en denkmoontlikhede gefragmenteer ${ }^{8}$. Daaraan korrespondeer 'n pluralisme van verwagtinge wat ten opsigte van sowel teologie as universiteit asook ten opsigte van die verhoudinge tussen hulle gekoester word. In 'n poging om 'n enigsins begaanbare weg deur hierdie struikgewas van opvattinge te vind, sou dit sinvol wees om kortliks te vra na die ontwikkeling van die verband waarin teologie en universiteit tot mekaar staan.

\section{DIE ONTWIKKELING VAN DIE MIDDELEEUSE UNIVERSITEITSIDEAAL}

Die vraag of die Christelike geloof enige verband kan hê met menslike geleerdheid is so oud soos die Christendom self. Reeds die apostel Paulus was bewus van die teenstelling wat tussen die wysheid van God en die wysheid van die wêreld kan bestaan ${ }^{9}$. En ongeveer anderhalf eeu later vra Tertullianus die ingrypende vraag: "wat het Athene met Jerusalem te doen? En welke verband bestaan daar tussen die akademie en die kerk?"10. Na sy oordeel het die geloof aan homself genoeg. Daar is geen behoefte aan die nuuskierigheid van verdere ondersoek nie. Dit is, volgens Tertullianus, juis die beginsel van die geloof dat daar niks buite die geloof te soek val nie ${ }^{11}$.

Die pas vermelde vraag van Tertullianus was een wat die kerk en die geestesgeskiedenis van die Westerse wêreld nie meer met rus sou laat nie. Alhoewel daar steeds weer diegene was wat òf ter wille van die suiwerheid van die godsdiens òf ter wille van die integriteit van die wetenskap rede en geloof streng geskeie wou hou, het andere weer volhardend gepoog om hierdie twee kragte te versoen. Ten spyte van hierdie teenstelling het dit tog mettertyd duidelik geword dat die Christelike geloof nie vir 'n intellektuele kultuur geslote was nie. Trouens, juis in hierdie opsig neem die Christendom ' $n$ unieke plek in die godsdiensgeskiedenis in. Meer as enige ander godsdiens het die Christelike geloof ' $n$ denkende religie geword'2. Dat dit die geval was, kan nie los gesien word van die intellektuele eise wat gestel is deur die fundamentele rol wat die Heilige Skrif ten opsigte van die geloof speel nie. Hierdie gesigspunt is reeds aan die begin van die Middeleeue beklemtoon deur die miskien te gemoedelike, maar tog diepsinnige beeld wat Gregorius die Grote ten opsigte van die Skrif gebruik het. Die Bybel, sê hy, is soos 'n stroom wat tegelyk heel vlak en baie diep is, 'n stroom waardeur 'n lam kan loop, maar 'n olifant moet swem'13. 
Sowel die vorm as die religieuse inhoud van die Skrif stel hoë eise aan die verstaans- en denkvermoë van diegene wat dit met erns lees.

Wanneer die eerste universiteite, tewete dié van Bologna en Parys in die twaalfde eeu tot stand kom en wanneer die universiteitswese so ontwikkel dat voor die einde van die Middeleeue in Europa van Brittanje en Frankryk in die Weste tot by Pole in die Ooste en van Spanje en Italië in die Suide tot by Skandinawië in die Noorde sowat tagtig universiteite voorkom, is ten spyte van al die verskille wat tussen hulle bestaan die faktor wat hulle gemeenskaplik gehad het, die feit dat hulle almal basies 'n Christelike karakter gedra het ${ }^{14}$. Dit sou $\cdot$ ook nog die geval wees toe die universiteit as instelling in die sestiende Eeu uit Europa oorgedra is in vele ander wêrelddele. Ook dan bly die Christelike karakter daarvan aanvanklik nog oorheersend.

Hiermee is uiteraard nie gesê dat die universiteit uit die Christendom voortgekom het of dat die verskeidenheid van wetenskappe uit die teologie gegroei het nie ${ }^{15}$. Wat egter wel waar is, is dat die teologie in die eenheidsvisie wat die middeleeuse wêreldbeeld oorheers het, 'n toonaangewende rol gespeel het ${ }^{16}$. Dit was die geval omdat hierdie eenheidsvisie ontwikkel het uit 'n sintese tussen die in die vroeë fase van die Renaissance herontdekte werke van Aristoteles en die oorgelewerde leer van die kerk'17. Op basis van hierdie eenheidsvisie soos dit in die middeleeuse studium generale beoefen is, kom die universitas magistrorum et scholarium dan tot stand. Alhoewel dit in die artes liberales wat sowel die trivium grammatika, retoriek en dialektiek as die quadrivium, astronomie, aritmetiek, geometrie en musiek omvat het, nie direk om die goddelike waarheid gegaan het nie, het dit daarin tog om 'n aanwending van die rede gegaan wat nie in stryd gekom het met die insigte van die teologie wat op die openbaring gegrond was nie ${ }^{18}$.

Die tydperk waarin die universiteite tot stand gekom het, was 'n tyd waarin daar groot ywer en entoesiasme vir geleerdheid openbaar is. Kulturele energie wat vir eeue latent was, breek $\operatorname{los}^{19}$. Die hele proses gaan gepaard met 'n histories-politieke ontwikkeling waarin sowel die kerk as die feodale heersers hulle magsgreep op die samelewing begin verloor. Studie begin wyer beoefen word as in die tot dan beperkte kring van klooster- en katedraalskole ${ }^{20}$. Leke kry toenemende toegang tot kulturele ontwikkeling en universitêr opgeleides begin langsaam 'n nuwe soort aristokrasie vorm. By die kragte van die sacerdotium en die imperium kom daar ' $n$ derde faktor by wat bydra tot die harmonieuse en geordende funksionering van die middeleeuse Corpus Christianum tewete die studium $^{21}$. In hierdie verband skryf Alexander van Roes in die dertiende 
eeu dat die idee van 'n Christelike gemeenskap vereis dat sentra van relatiewe outonomie daargestel word wat die samelewing kan beskerm teen vergrype wat in die naam van vroomheid of patriotisme gepleeg word ${ }^{22}$. Hy gaan selfs so ver as om die universiteit die profetiese arm te noem van die omvattende werk van God. Dit is na sy oordeel die universiteit se taak om sowel die staat as die kerk aan hulle grense te herinner sodat die welsyn van die hele gemeenskap gehandhaaf kan word23.

Maar die taak van die universiteit is in terme van die middeleeuse denke nie net negatief nie. Dit is ook sy verantwoordelikheid om die geleerde tradisie van die oudheid so te bewaar dat dit die ware vroomheid onder die mense kan bevorder. Die studie van die Griekse en Latynse klassieke is so behartig dat dit steeds in ooreenstemming met die Christelike openbaring gebring is. So ontstaan 'n kultuur waarin die liefde vir geleerdheid en liefde vir God verenig word 24 . Staat en kerk het die belang van hierdie derde gesagsfaktor in die samelewing goed begryp en het daarom die nodige ruimte en toegewings daarvoor gemaak.

Vra 'n mens na die kenmerkende elemente van die universiteitskultuur soos dit tot in hierdie stadium ontwikkel het, dan kan veral die volgende eienskappe beklemtoon word: In die eerste instansie is die universiteit deur universaliteit gekenmerk. Die werk wat daar gedoen is, was ekumenies van aard in die sin dat mense van enige nasionaliteit daaraan kon meedoen. Akademiese grade het toestemming verleen om op enige plek onderrig te gee - die licentia ubique docendi. Universiteitsprosedures op organisatoriese en akademiese vlak was oral min of meer dieselfde ${ }^{25}$.

Tweedens was die universiteit oop vir diversiteit nie alleen in die sin dat ' $n$ veelheid van vakke bestudeer is nie, maar ook in dié opsig dat verskille tussen akademiese skole en benaderings verdra is. Dit was ook die geval waar vakke met mekaar oorvleuel het. So het die teologie as sacra doctrina homself beskou as 'n dissipline wat fundamenteel van die filosofie verskil. Met laasgenoemde term is destyds die vakke aangedui wat deur die ratio bepaal is. Trouens, juis die worsteling met en die betrokkenheid by die filosofie het in 'n groot mate bygedra tot die ontwikkeling van die teologie.

In die derde plek was die universiteit gerig op diens aan die gemeenskap26. Dit blyk uit die samestelling van die universiteit. 'n Volledige universiteit het in die Middeleeue uit vier fakulteite bestaan. Die fakulteit van die artes liberales het die onderbou gevorm vir die "hoëre" fakulteite, tewete dié van geneeskunde, regte (kerklike en wêreldlike reg) en teologie ${ }^{27}$. Hiermee het die universiteit uitdrukking gegee aan die feit 
dat hy met die basiese behoeftes van die mens erns gemaak het. Hierdie behoeftes is die bevryding van siekte, die stryd teen onreg en die redding tot die ewige lewe. Aan hierdie behoeftes korrespondeer die beroepe van geneesheer, regsgeleerde en predikant. Die universiteit wou bydra ten opsigte van die voorbereiding tot die bekleding van hierdie ampte. Selfs die algemene voorbereiding op die toegespitste studie vir hierdie beroepe soos dit in die bestudering van die artes liberales gebied is, is beskou as diens aan die gemeenskap in die sin van 'n stryd teen onkunde en dwaasheid28.

\section{DIE IDEALISTIESE UNIVERSITEITSIDEAAL}

'n Besondere fase in die ontwikkeling van die klassieke universiteitsideaal is dié wat met die totstandkoming van die Friedrich Wilhelm Universiteit te Berlyn gepaard gegaan het. Tot hierdie gestaltegewing van die universiteitsideaal, wat as neo-humanisties - idealisties bekendstaan, het veral denkers soos Wilhelm von Humboldt en J G Fichte bygedra ${ }^{29}$. Kenmerkend van hierdie opvatting aangaande die universiteit is dat dit die ontwikkeling wat sedert 1806 in Frankryk voorgekom het, nadruklik afwys. Die Napoleon-tiese universiteit is naamlik sy outonomie ontneem en direk in diens van die staat gestel. Daarmee gaan gepaard dat beroepsonderwys tot eintlike taak van die universiteit gemaak word en dit dan met die bedoeling dat daarmee die stabiliteit van die staat bevorder moet word ${ }^{30}$. Teen hierdie Franse ontwikkeling stel Von Humboldt cum suis dan die ideaal van die universiteit "im deutschen Sinn". Daarmee bedoel hulle dat dit nie die doel van die universitêre wetenskapsbeoefening is om aan die studente prakties bruikbare kennis by te bring nie. Aan hulle "höhere Lehranstalt", oordeel die vaders van die Berlynse universiteit, moet die wetenskap nie beoefen word ter wille van praktiese doeleindes nie. Die wetenskap moet suiwer wetenskap wees in dié sin dat die waarheid daarin gesoek word ter wille van die waarheid self. Dit sal begryplik wees dat Von Humboldt en sy medestanders met die idee van 'n suiwere wetenskap veral die filosofie op die oog het. Die ander dissiplines kan daarby gereken word in soverre die wysgerige dimensie daarvan in aanmerking geneem word. Die blootstelling van die studente aan die wetenskapsbeoefening in hierdie sin moet lei tot die ontplooiing en morele verdieping van hulle persoonlikhede.

'n Belangrike element van die neo-humanisties-idealistiese universiteitsideaal van Von Humboldt en Fichte was die gedagte van akademiese vryheid en akademiese eensaamheid. Aangesien dit aan 'n universiteit in die eerste instansie om die soeke na die waarheid gaan, moet studente en dosente vry wees om te bestudeer wat hulle wil. Ten einde hierdie strewe 
moontlik te maak moet die studie en ondersoek dan ook in 'n sekere afgesonderheid van die gemeenskap geskied. Alleen so kan belangeloosheid en objektiwiteit in die soeke na die waarheid verseker word ${ }^{31}$.

In die twintigste eeu is die universiteitsideaal wat aan die name van Fichte en Von Humboldt verbonde is, in hoofsaak veral deur Karl Jaspers voortgedra en uitgebou ${ }^{32}$. $\mathrm{Na}$ sy oordeel bestaan die eie aard van universitêre onderrig daarin om die student te laat deelneem aan die proses van wetenskaplike ondersoek. Langs hierdie weg kan die student 'n wetenskaplike ingesteldheid ontwikkel. Opvallend in die visie van Jaspers is sy beklemtoning van die gegewe dat die ware wetenskaplike houding 'n etiese dimensie het ${ }^{33}$. Daarmee bedoel hy dat dit gepaardgaan met 'n strewe na objektiwiteit, met 'n openheid vir kritiek, onafhanklikheid van oordeel, 'n verantwoordelikheidsbewussyn en die wete dat die eie insig begrens is. Verder beklemtoon Jaspers die gegewe dat alle kennis ten diepste 'n eenheid vorm. Dat dit die geval is, hang saam daarmee dat die werklikheid waarop die kennis gerig is, in laaste instansie, een is. Juis daarom is dit van belang dat die verskillende wetenskappe binne die eenheidsverband van die universiteit ondersoek en onderrig word ${ }^{34}$.

Aangesien die universitêre onderrig- en leerproses volgens Jaspers onafskeidelik verbonde is aan wetenskaplike ondersoek, moet die universiteit nie te sterk by vakonderrig of beroepsonderwys in die eng sin van die woord betrokke wees nie. Dit beteken egter dat die universiteit omring moet wees met 'n hele konstellasie van instellinge wat spesifiek op praktiese beroepsvaardighede afgestem is ${ }^{35}$.

'n Verdere denker wat 'n belangrike invloed uitgeoefen het op die vorming van die moderne universiteitsideaal was John Henry Newman ${ }^{36}$. Alhoewel hy op verskillende punte van Von Humboldt verskil, is daar tog ook 'n groot mate van ooreenstemming met laasgenoemde. Die vernaamste punt van verskil bestaan daarin dat hy die beklemtoning van die belang van die eenheid van onderrig en ondersoek afwys. Die eintlike taak van die universiteit is na sy oordeel die oordrag en verbreiding van kennis. In hierdie oordrag van kennis gaan dit daarom dat die student 'n "liberal education" bygebring word. Hieronder word verstaan die kultivering van intellektuele uitnemendheid. Die bedoeling hiervan is nie in die eerste instansie die vermeerdering van dit wat die student weet nie, maar die daarstelling van 'n bepaalde geestesgesteldheid wat ook 'n "philosophical habit" genoem kan word. Hierdie "habit of mind", wat die student deur sy hele lewe bybly, word gekenmerk deur "freedom, equitableness, calmness, moderation, and wisdom" ${ }^{37}$. Hierdeur kry die student 'n geïntegreerde en 
gebalanseerde visie op die werklikheid wat nie alleen intellektuele vorming inhou nie, maar wat ook neerslag vind in 'n hele lewenshouding tewete dié van 'n "gentleman". Hieruit word egter ook duidelik dat universiteitsonderrig volgens Newman, nie gerig is op 'n nut wat buite die vorming self geleë is nie. Die universiteit is ook vir hom nie in die eerste instansie op beroepsopleiding ingestel nie. Hy lê klem daarop dat die verwerwing van 'n ontwikkelde gees in sigself waardevol is. Die universiteit is dus nie 'n losse versameling beroepsopleidinge nie ${ }^{38}$. In die lig van voorafgaande is dit begryplik waarom Newman die universiteit eerder "a place of education than of instruction" noem ${ }^{39}$. Dit sal verder ook duidelik wees dat alhoewel sy opvattinge van dié van Von Humboldt verskil in verband met die kwessie van die eenheid van onderwys en ondersoek aan die universiteit, die ideaal wat hy vir universiteitsonderrig koester tog in 'n groot mate ooreenstem met dié van Von Humboldt ${ }^{40}$.

Waar die middeleeuse universiteit daarin geslaag het om sy ideële en funksionele dimensies harmonieus te integreer, toon die moderne ontwikkeling die verskynsel dat hierdie twee dimensies enigsins uit mekaar uit beweeg. Weliswaar kom dit nie tot volkome ideële of liberale universitale aan die een kant en totale funksionele universiteite aan die ander kant nie ${ }^{41}$. Dit is eerder so dat sommige universiteite meer ooreenkom met die idee van 'n liberale universiteit terwyl ander maar meer die vorm van 'n funksionele universiteit aanneem. En miskien sou 'n mens selfs moet sê dat die moderne universiteit steeds 'n sekere innerlike spanning vertoon tussen hierdie twee pole of dimensies wat in sy bestaan teenwoordig is. Die omstandighede en beperkinge van die bepaalde situasie waarin so 'n universiteit hom bevind, lei dan daartoe dat één van hierdie twee inherente moontlikhede sterker op die voorgrond tree as die ander ${ }^{42}$.

Hierdie vlugtige oorsig oor die belangrikste opvattinge wat ten grondslag lê aan die ontwikkeling van die universiteitswese in die moderne tyd bring aan die lig dat dit wat ons die universiteitsideaal noem in toevoeging tot die motiewe van universaliteit, diversiteit en gemeenskapsdiens wat in die Middeleeue sterk na vore getree het, ook nog die volgende elemente bevat: In die eerste instansie is dit kenmerkend van die universiteit dat die eenheid van die waarheid daarin beklemtoon word sodat al die wetenskappe in beginsel 'n eenheid vorm. Daarmee is natuurlik nie gesê dat alle wetenskappe ewe fundamenteel is nie. Tog maak hulle almal deel uit van dieselfde geheel. Tweedens is dit eie aan die universitêre soeke na die waarheid dat dit in vryheid geskied. Dit beteken dat in die beoefening van die wetenskap an die universiteit slegs die waarheid self bepalend mag wees vir dit wat as waar erken word ${ }^{43}$. Ten einde hiervoor 
sorg te dra, behoort die wetenskapsbeoefening aan die universiteit, in die derde plek, ook deur 'n sekere eensaamheid gekenmerk te word. Daarmee word bedoel dat die universiteit juis ter wille van die diens wat dit moet lewer 'n sekere afstand ten opsigte van ander samelewingsverbande behoort te handhaaf44. Daarmee word nie bedoel dat daar nie 'n sekere gemeenskapsgerigtheid in die wetenskapsbeoefening mag wees nie. Hierdie maatskaplike gerigtheid mag egter nie die onafhanklikheid van die universiteit in die gedrang bring nie.

Die maatskaplike gerigtheid waarvan hier sprake is, kom die duidelikste tot uitdrukking in die feit dat die universiteit naas 'n gemeenskap van ondersoekers verder ook 'n onderwysinstelling is. Die universiteit berei mense voor om ' $n$ bepaalde beroep in die samelewing te beklee. Hierdie gesigspunt is reeds hierbo vermeld toe die middeleeuse universiteitsideaal beskryf is. Wat in die moderne tyd deur denkers soos Von Humboldt en Jaspers beklemtoon word, is dat hierdie onderwys geskied in samehang met die ondersoektaak van die universiteit. Die vierde element van die moderne universiteitsideaal is dus die beginsel van die eenheid van ondersoek en onderwys aan die universiteit. In die lig hiervan sal dit duidelik wees dat die universitêre onderwys volgens die idealisties liberale ideaal daarvan nie in die eerste instansie beroepsonderwys is in dié sin dat dit die student slegs beroepsvaardighede wil bybring nie, maar dat dit 'n wetenskaplike instelling of mentaliteit wil oordra op grond waarvan iemand selfstandig en onafhanklik kan dink. Universitêre onderwys verskil van hoëre beroepsonderwys daarin dat dit op 'n hoër vlak van abstraksie beweeg en nie direk vra na die praktiese toepassing daarvan nie terwyl dit tewens in 'n oordragsvorm geskied waardeur die selfstandige kennisverwerwing van die student gestimuleer word 45 .

In laaste instansie $\mathrm{kan}$ as vyfde element van die moderne universiteitsideaal aangedui word die strewe om nie alleen die akademiese insig van die student te verskerp nie, maar om hierdie intellektuele vorming so te hanteer dat dit die omvattende persoonlikheidsontwikkeling van die student ten goede kom.

\section{TEOLOGIE EN UNIVERSITEIT}

Nadat die ontwikkeling van die universiteitsideaal in breë trekke nagegaan is, kan vervolgens in die lig daarvan, meer konkreet die vraag aan die orde gestel word of teologiebeoefening in teologiese opleiding aan 'n universiteit behoort te geskied. Die metode wat by die hantering van hierdie vraag gevolg word, bestaan daarin dat eers 'n aantal stellings oor die 
aangeleentheid gemaak word wat daarna van 'n kort toeligting voorsien word.

Die stellings is die volgende:

1 Die vraag na die oord waar die teologie beoefen en predikante opgelei word, is nie in die eerste plek van strategiese nie maar van prinsipiële aard. Die vraag na die oord en aard van teologiese opleiding is self ' $n$ teologiese vraag.

2 Die teologie is 'n dimensie van die gebeure waarin die Woord van God en die Christelike geloof op mekaar afgestem is en waarin die kerk in aansyn geroep en in stand gehou word.

3 Die teologiese diens aan die kerk dra die karakter van institusionalisering en verantwoording.

4 Sowel die inhoud as die prosedures en metodes van die teologie veronderstel en gee aanleiding tot denke van die hoogste wetenskaplike standaard.

5 Die teologie dra naas 'n kerklike ook 'n wetenskaplike karakter en moet verkieslik beoefen word in 'n omgewing wat gekenmerk word deur die tradisionele erflikheidselemente van die universiteit.

6 Onder erflikheidselemente van die universiteit word, onder andere verstaan gegewens soos universaliteit, eenheid, diversiteit, waarheid, vryheid, eensaamheid, persoonlikheidsvorming en gemeenskapsgerigtheid.

7 Ter wille van die diens wat die universiteit aan die gemeenskap en aan die kerk lewer, moet die universiteit 'n sekere afstand ten opsigte van hierdie samelewingsverbande handhaaf.

8 Die universiteitswese in Suid-Afrika gaan in 'n toenemende mate gekenmerk word deur 'n worsteling tussen die tradisionele erflikheidselemente van die universiteit aan die een kant en kontekstuele eise aan die ander kant.

9 Om die teologie aan die universiteit te onttrek, hou 'n mosie van wantroue in ten opsigte van die waarheidsaard en waarheidsrele- 
vansie van die Christelike evangelie terwyl so tewens 'n fundamentele waarheidsdiens aan die universiteit weerhou en ' $n$ belangrike toegangsweg tot die gemeenskap verbeur word.

10 Solank as wat 'n bepaalde universiteit aan die teologie ruimte bied om sy eie aard uit te leef, moet die kerk meewerk om dit in daardie konteks te laat beoefen.

11 Die universiteit behoort ter wille van sy eie aard die teologie binne die ensiklopedie van wetenskappe te hou.

12 Indien dit sou gebeur dat die teologie teen sy wil uit 'n universiteit gedwing word, kan dit wel sinvol in 'n kerklike akademie of seminarie beoefen word. Dit is egter ' $n$ weg wat alleen in 'n noodtoestand gevolg moet word.

Die vraag of die teologie aan 'n universiteit tuishoort, is een wat sake ter sprake bring wat van 'n groter omvang en diepgang is as wat met 'n eerste oppervlakkige kennismaking daarmee vermoed kan word. Nie alleen is dit 'n kwessie wat, soos uit die voorafgaande paragrawe geblyk het, 'n lang en ingewikkelde geskiedenis deurloop het nie, maar dit is ' $n$ aangeleentheid wat fundamentele vrae van 'n teologiese en filosofiese aard aan die orde stel. Daarmee is gesê dat die vraag of die teologie aan die universiteit tuishoort nie alleen maar op strategiese oorwegings berus nie. Wie verantwoord op hierdie vraag wil reageer, sal naas antwoorde van 'n politieke en wetenskapsteoretiese aard veral ook 'n prinsipieel teologiese antwoord daarop moet gee ${ }^{46}$. Daarom is die eerste stelling wat gemaak word die volgende: Die vraag na die aard waar die teologie beoefen en predikante opgelei word, is nie in die eerste plek van strategiese nie, maar van prinsipiële en met name ook teologiese aard.

Verder moet die aandag daarop gevestig word dat die teologie nie iets vreemds is aan die Christelike openbaring, die Christelike geloof en die kerk nie. Trouens, die teologie is inherent daaraan verbonde. Daarom lui die tweede stelling: Die teologie is ' $n$ dimensie van die gebeure waarin die Woord van God en die Christelike geloof op mekaar afgestem is en waarin die kerk in aansyn geroep en in stand gehou word. Die vraag is dus nie òf die teologie by die kerk betrokke moet wees nie. Die vraag is hoogstens hoe die teologie daarby betrokke is. In antwoord hierop sou 'n veelheid van gesigspunte ter sprake gebring kon word. Vir die tema wat hier onder bespreking is, is egter veral die twee aspekte van belang wat in 
stelling drie aan die orde kom: Die diens van die teologie aan die kerk dra die karakter van institusionalisering en verantwoording. Met institusionalisering word hier bedoel dat die teologie die weg is waarlangs voornemende predikante vir hulle taak voorberei word deur hulle te oriënteer ten opsigte van die inhoud, grondbeginsels, prosedures en praktyke van die kerklike bediening. Hierdie rol van die teologie is algemeen bekend. Daarom is dit van fundamentele belang dat die tweede gesigspunt wat in hierdie stelling vermeld word, beklemtoning kry. Dit gaan in die teologie dus nie alleen maar om die opleiding van predikante nie. Die teologie is ook die middel waardeur die kerk die impak van nuwe ontwikkelinge en denkomwentelinge verwerk. Hierdie is 'n gesigspunt wat in die huidige tyd nie oorbeklemtoon kan word nie. Die steun wat die Gereformeerde Protestantisme lank van die kant van die staat en staatsinstellings ontvang het, is besig om ten einde te loop. Die kerke van Gereformeerde herkoms sal spoedig merk dat hulle 'n minderheidsidioom van die Christendom in SuidAfrika verteenwoordig. Enige kerk wat hierdie idioom op prys stel en die erfenis wat dit weerspieël, sal bereid moet wees om teologiese fasiliteite in stand te hou wat 'n bydrae kan lewer om hierdie posisie te verantwoord, verder te ontwikkel en die positiewe rol wat dit in kerk en samelewing kan speel te ontgin.

Dit is egter so dat die teologie nie alleen kerklik van aard is nie. Stelling vier lui: Sowel die inhoud as die prosedures en metodes van die teologie veronderstel en gee aanleiding tot denke van die hoogste wetenskaplike standaard. Alhoewel die teologie in die kerk 'n fundamentele rol speel, is die oorkoepelende doel van die kerk nie die beoefening van die wetenskap nie. Daarvoor het oor die afgelope agt honderd jaar die universiteit as instelling ontwikkel wat konsentreer op die beoefening van die wetenskap by wyse van onderrig en navorsing. Op grond daarvan word in stelling vyf ' $n$ beslissende keuse gemaak wanneer gesê word dat die teologie verkieslik beoefen moet word in 'n omgewing wat gekenmerk word deur die tradisionele erflikheidselemente van die universiteit ${ }^{47}$.

Nou moet dadelik gesê word dat die aarselende terme waarin hierdie stelling geformuleer word, opvallend kontrasteer met die logiese rigting waarin die betoog tot dusver skyn te beweeg. Dat dit die geval is, hang saam daarmee dat in die twintigste eeu daar nie meer 'n universeel aanvaarde en enkelvoudige universiteitsidee bestaan soos dit in die Middeleeue die geval was of ook nog in die hoogbloei van die idealisme wat die stigting van die universiteit van Berlyn in 1810 omgewe het nie.

Daar is egter 'n tweede rede waarom die keuse van stelling vyf met die term "verkieslik" gekwalifiseer word. Dit is dat die tradisionele 
erflikheidselemente van die universiteit wat in stelling ses vermeld word, in die huidige tyd onder al groter druk te staan kom.

Om hierdie uitspraak te verstaan, is dit eers nodig om kortliks iets te sê oor dit wat hier met die term "tradisionele erflikheidselemente" van die universiteit bedoel word. $\mathrm{Al}$ is dit so dat daar tans nie 'n universeel aanvaarde universiteitsidee bestaan nie, is dit tog so dat die universiteit oor die eeue heen 'n verbasende stabiliteit vertoon. Dit hang saam daarmee dat, soos hierbo aangetoon is, bepaalde gegewens hulle algaande aan die universiteit as instelling geheg het en daarin geslaag het om hulle eeu na eeu te handhaaf. Juis daarom word van hulle as die erflikheidselemente van die universiteit gepraat. Konkreet word hier bedoel elemente soos eensaamheid, vryheid ensovoorts.

'n Belangrike motief wat uit hierdie erflikheidselemente spreek, is die feit dat die universiteit, ter wille van die diens wat dit aan die samelewing moet lewer, 'n sekere outonomie en selfstandigheid moet hê. Waar die waarheid suiwer in perspektief moet kom, moet op die soeke daarna liefs nie te veel eksterne invloede inwerk nie. Vandaar dat stelling sewe uitspreek dat ter wille van die diens wat die universiteit aan die gemeenskap en aan die kerk lewer, dit 'n sekere afstand ten opsigte van hierdie samelewingsverbande moet handhaaf.

Presies op hierdie punt tree die druk van die eksterne invloede waarvan daar sopas sprake was, egter in. In hierdie verband is stelling 8 ter sake: Die universiteitswese in Suid-Afrika gaan in 'n toenemende mate gekenmerk word deur 'n worsteling tussen die tradisionele erflikheidselemente van die universiteit aan die een kant en kontekstuele eise aan die ander kant. Onder die vaandel van kontekstualiteit met sy slagspreuk van relevansie sal die tradisionele gestalte van die universiteit al meer in gedrang kom. Maar ook die faktor van finansiële bekostigbaarheid wat dreig om van die waarheid 'n handelsartikel te maak, sal druk op die eiesoortigheid van die universiteit plaas. Dit is ook denkbaar dat namate die proses van sekularisasie toeneem 'n wetenskapsbegrip by sommige universiteite gevestig kan raak wat vir die teologie as wetenskap geen ruimte meer laat nie. Verder is dit ook voorstelbaar dat die motief van godsdiensgelykheid, soos dit tans in die Verenigde State van Amerika die geval is, daartoe kan lei dat van staatsweë bepaal word dat aan 'n openbare universiteit nie meer religie gepraat mag word nie, maar hoogstens oor religie. Dit sou dan impliseer dat teologiese inhoude nie in 'n tetiese sin aan die orde kan kom nie dog slegs in 'n historiese of vergelykend godsdienswetenskaplike sin.

Waar kragte soos hierdie ongekontroleerd op die universiteitswese sou inwerk, sou dit daartoe kon lei dat die eenheidsideaal in verband met 
die waarheid en die waarheidsoriëntasie in die wetenskapsbeoefeing in die gedrang kan kom. En waar 'n universiteit sy primêre waarheidsoriëntasie kwytraak, verword akademiese vryheid tot anargie en waarheid tot 'n onverbonde versameling akademiese korrekthede. Dit is in hierdie verband dat die teologie die universiteit van diens kan wees. Die teologie kan die vraag na die diepste sin en oriëntasie in die universiteit wakker hou. Daarom lui stelling nege: $\mathrm{Om}$ die teologie aan die universiteit te onttrek, hou 'n mosie van wantroue in ten opsigte van die waarheidsaard en waarheidsrelevansie van die Christelike evangelie, terwyl so tewens 'n fundamentele waarheidsdiens aan die universiteit weerhou en 'n belangrike toegangsweg tot die gemeenskap verbeur word. Indien die kerk die teologie sou onttrek aan dié instelling waar die mees gevorderde kennis in die gemeenskap bestudeer en ontgin word, sal dit onafwendbaar lei tot 'n verdere marginalisering van die Christelike geloof en die kerk in die samelewing. Die konklusie in stelling tien is dus belangrik: solank as wat 'n bepaalde universiteit aan die teologie ruimte bied om sy eie aard uit te leef, moet die kerk meewerk om dit in daardie konteks te laat beoefen.

En dit dan nie net ter wille van die kerk nie, maar ook ter wille van die universiteit. Daarom konkludeer stelling elf dat die universiteit ter wille van sy eie aard die teologie binne die ensiklopedie van die wetenskappe behoort te hou. Waar daar - soos dit in 'n universiteit behoort te gebeur op 'n omvattende wyse kennis ontgin word, kan teologiese vrae of dan ten minste vrae van 'n teologiese strekking nie vermy word nie. Die vraag is dus nie of daar aan 'n universiteit teologie moet wees of nie. Dit is in elk geval daar. Die vraag is eerder of dit goeie of slegte teologie sal wees. Om goed te wees, moet dit toevertrou word aan 'n fakulteit wat toegerus is om dit op 'n verantwoorde wyse te hanteer.

Waar kragte soos dié wat hierbo vermeld is sonder weerstand op die universiteitswese sou inwerk sou die scenario van stelling twaalf aan die orde kon kom. Daar word gesê: Indien dit sou gebeur dat die teologie teen sy wil uit 'n universiteit gedwing word, kan dit wel in 'n kerklike akademie of seminarie beoefen word ${ }^{48}$. Dit is egter 'n weg wat alleen in 'n noodtoestand gevolg moet word.

In die pas vermelde stelling word universiteitsfakulteit en seminarie as wedersyds uitsluitende moontlikhede gesien. Aan die ander kant is dit natuurlik ook so dat hulle as aanvullende opsies beskou kan word. So 'n gedagte het nie alleen sy wortels ver terug in die ontwikkeling van die universiteitswese nie, maar weerspieël 'n praktyk wat vir die huidige SuidAfrikaanse opset aan populariteit wen. Wat dit egter presies behels, moet nog verder ondersoek word. 


\section{NOTAS:}

1 Vergelyk I L F Ferreira, Die teologiese seminarie van Stellenbosch 1858-1963, Ongepubliseerde proefskrif, Universiteit van Stellenbosch, 1972 asook D R de Villiers, Die agtergrond en ontwikkeling van die teologiese opleiding deur die Nederduitse Gereformeerde Kerk in Suid-Afrika, Ongepubliseerde proefskrif: Universiteit van Pretoria, 1972.

2 Vergelyk A König, "Ekumeniese Teologie”, in: I H Eybers, A König en J A Stoop (reds), Inleiding in die Teologie, Pretoria 1978, 326-328. Kyk verder ook L O K Lategan, Die wese van die Universiteit: 'n Histories-strukturele perspektief, Bloemfontein 1989, 108-126 asook Idem, "Die NG Kerk se teologiese fakulteite by 'n kruispad: die toekoms van hierdie fakulteite in 'n veranderende universiteitsopset", NGTT 37/2 (1996), 360-369.

3 'n Dergelike proses is ook in Duitsland aan die gang. Hier het die veranderinge wat in Oos-Europa plaasgevind het ook die diskussie oor die plek van teologiese fakulteite op gang gebring. Kyk M Seckler, "Kann und soll die Theologie an der Universität Zukunft haben?” ThQ 171/4 (1991), 246.

4 Vergelyk G Ebeling, "The Bible as a document of the university”, in: The Bible as document of the University (edited by H D Betz) Chicago 1981, 16 asook M Seckler, ThQ 171/4 (1991), 244.

$5 \quad$ Kyk D Tracy, The analogical imagination. Christian Theology and the culture of pluralism, London 1981, 3-46. Tracy se opvatting oor die oord van die teologie het in die huidige tyd wye bekendheid verwerf. Hy was egter nie die eerste denker om hierdie gedagtegang te ontwikkel nie. In 'n sekere sin tref 'n mens dit reeds aan in die beskouinge wat Kant oor die wese en taak van die universiteit gehad het. Vergelyk in hierdie verband G Bien, "Kant's Theorie der Universität und ihr geschichtlicher Ort", Historische Zeitschrift 219/3 (1974), 551-577 asook D Rössler, "Religion vom Katheder. Evangelische Theologie an der Universität”, Evangelische Kommentare 16 (1983), 312-314.

$6 \quad$ D Rössler, $a w, 1983,312$.

7 Vergelyk Ebeling, "Die theologische Verantwortung und ihre institutionelle Wahrnehmung", Zeitschrift für Evangelisches Kirchenrecht 31 (1986), 1-26.

8 Vergelyk A E McGrath, "The challenge of pluralism for the contemporary Christian church", JETS 35/3 (1992), 487-501.

9 Vergelyk 1 Korintiërs 1:18-25. Kyk ook H Vogel, "Die Stellung der Theologie im Raume der Universität”, ThLZ 82/10 (1957), 721-730.

10 Vergelyk Ebeling, $a w, 1981,6$. 
$11 \quad$ Ebeling, $a w, 1981,6$.

12 Vergelyk Ebeling, $a w, 1986,8$.

$13 \quad$ Kyk Ebeling, $a w, 1981,20$.

$14 \quad$ Vergelyk Ebeling, $a w, 1981,6$.

15 Vergelyk H Barth, "Das Recht unserer theologischen Fakultät", Zwischen den Zeiten 6 (1928), 484.

16 Vergelyk H Vogel, $a w, 723$.

$17 \quad$ Kyk Ebeling, $a w, 20$.

18 Vergelyk Vogel, $a w, 724$. Kyk ook J C Hough, "The marginilization of theology in the university", in: J M Kitagawa (ed), Religious studies, theological studies and the university-divinity school, Atlanta 1992, 37.

19 Vergelyk Ebeling, $a w, 1981,8$.

20 Vergelyk L O K Lategan, $a w, 28-29$.

21 Vergelyk W Kasper, "Wissenschaftliche Freiheit und lehramtliche Bindung der Katholischen Theologie", in: H Marré und J Stüting (Hrsg), Theologie und Universität (Essener Gespräche zum Thema Staat und Kirche 16), Münster $1982,20-21$.

22 J C Hough, “The university and the common Good", in: D R Griffin and J C Hough (eds), Theology and the university (Essays in honor of John B Cobb, jr), Albany 1991, 102.

23 Vergelyk H Grundman, Art Alexander von Roes, RGG I, 231.

24 Kyk J Le Clerq, The love of learning and the desire for God: A study of monastic culture, London 1978, 139-141 asook J C Hough, a w, 102.

$25 \quad$ Kyk Ebeling, $a w, 1981,8$.

26 Vergelyk Barth, $a w, 484-485$.

27 Kyk Barth, $a w$, 484. Vergelyk ook G E Meuleman, "Theologie aan de universiteit”, GTT 91 (1991), 1.

28 Vergelyk Ebeling, $a w, 1981,9$. 
29 Kyk W Weischedel (Hrsg), Idee und Werklichkeit einer Universität, Berlin 1960. Vergelyk ook G E Meuleman, $a w, 2$.

$30 \quad$ Kyk Meuleman, $a w, 3$.

31 Vergelyk Meuleman, $a w, 5$.

32 Kyk K Jaspers, Die Idee der Universität, Berlin 1961. Vergelyk ook Meuleman, $a w, 6$.

33 Vergelyk Meuleman, $a w, 7$.

$34 \quad$ Kyk ook Meuleman, $a w, 13$.

35 Vergelyk Meuleman, $a w, 7$.

36 Kyk veral J H Newman, The idea of a university, Garden City, New York 1959.

37 Kyk Newman, $a w, 129$. Vergelyk ook Hough, $a w, 37$ asook Meuleman, $a w$, 8.

38 Vergelyk Meuleman, $a w, 10$.

39 Kyk Newman, $a w, 105$ en vergelyk Meuleman, $a w, 9$.

$40 \quad$ Vergelyk Hough, $a w, 49$.

$41 \quad$ Kyk Meuleman, $a w, 12$.

42 Vergelyk P F Fransen, "The teaching of theology on continent and its implications”, in: J Coulson (ed), Theology and the university. An ecumenical investigation, Baltimore and London 1964, 96.

43 Vergelyk Meuleman, aw, 14 asook W C Spohn, "Between church and academy: the dilemma of American Catholic theology", in: Kitagawa, $a w, 15$.

44 Vergelyk Meuleman, $a w, 15$.

45 Ek sluit hier aan by 'n formulering van A H G Rinnooy soos aangehaal deur Meuleman, $a w, 15$.

46 Vergelyk Ebeling, "Zur Existenz theologischer Fakultäten an staatlichen Universitäten”, in: Idem, Wort und Glaube III, Tübingen 1975.

47 Die term "erflikheidselemente" ontleen ek aan die werk van $\mathbf{H}$ W Rossouw, Universiteit, wetenskap en kultuur, Kaapstad 1993, 32. 
48 Vergelyk K A Schippers, "Ook op de Kamper wijze", in: Het leven is meer dan ethiek (Festschrift vir G Rothuizen), Kampen 1987, 83-93. 